\title{
Global distribution and climatic match of a highly traded ornamental freshwater fish, the sailfin molly Poecilia latipinna (Lesueur, 1821)
}

\author{
Nicholas Koutsikos ${ }^{1,2}$, Leonidas Vardakas ${ }^{1, *}$, Eleni Kalogianni ${ }^{1}$ and Alcibiades N. Economou ${ }^{1}$ \\ ${ }^{1}$ Hellenic Centre for Marine Research, Institute of Marine Biological Resources and Inland Waters, Anavissos, 19013 Attica, Greece \\ 2 Department of Environment, University of the Aegean, Mytilene 81100, Greece
}

\begin{abstract}
Predicting alien species' establishment through climate matching may inform management actions preventing future invasions. The aim of the current study was to evaluate the climate match of the sailfin molly (Poecilia latipinna) worldwide, with emphasis on Europe and the Mediterranean. A literature review indicated that the species presents a total of 100 non-indigenous occurrences in 29 countries worldwide. Predominantly, it has been introduced within tropical/subtropical climatic zones, where it is usually clustered near ornamental trade centers and malaria affected areas. Overall, sailfin molly distribution reflects a warm-stenothermic tolerance, however, there are validated populations outside the subtropical belt in geothermally heated water bodies. Its invasion potential, assessed by Climatch tool, indicated a low environmental match ( $5 \%$ of the assessed sites) within Europe, whereas in the Mediterranean this rose to $60 \%$, though the species is recorded only at one location. This poor match of the model's output may reflect its inability to take into account local environmental filters. Intolerance to prolonged temperature drops appears to be the leading factor constraining sailfin molly establishment in Europe. Additional constrains on its successful invasion, i.e. specialized habitat requirements, limited propagule supply or reduced reproductive fitness, due to breeding manipulations of commercially available strains, are discussed.
\end{abstract}

Keywords: climate matching / dispersal / invasive / ornamental / poeciliids

Résumé - Correspondance climatique de la distribution mondiale d'un poisson ornemental d'eau douce hautement commercialisé, le molly voile Poecilia latipinna (Lesueur, 1821). La prévision de l'établissement d'espèces exotiques par la correspondance climatique peut éclairer les mesures de gestion visant à prévenir de futures invasions. L'objectif de la présente étude était d'évaluer la correspondnace climatique du molly voile (Poecilia latipinna) dans le monde entier, en mettant l'accent sur l'Europe et la Méditerranée. Une analyse bibliographique a révélé que l'espèce présente un total de 100 occurrences non indigènes dans 29 pays à travers le monde. La plupart du temps, elle a été introduite dans les zones climatiques tropicales/subtropicales, où elle est généralement regroupée à proximité des centres commerciaux d'aquariophilie et des zones touchées par le paludisme. Dans l'ensemble, la distribution du molly voile reflète une sténothermie pour les eaux chaudes, mais il existe des populations validées en dehors de la ceinture subtropicale dans les plans d'eau réchauffés par sources chaudes. Son potentiel invasif, évalué par l'outil Climatch, indique une faible concordance environnementale (5\% des sites évalués) en Europe, alors qu'en Méditerranée ce taux passe à $60 \%$, bien que l'espèce ne soit signalée qu'à un seul endroit. Cette mauvaise adéquation des résultats du modèle peut refléter son incapacité à prendre en compte les filtres environnementaux locaux. L'intolérance aux baisses de température prolongées semble être le principal facteur limitant l'établissement du molly voile en Europe. D'autres contraintes liées à la réussite de son invasion, c.-à-d. les exigences en matière d'habitat spécifique, le nombre limité de propagules ou la fécondité réduite due aux manipulations de souches de reproducteurs disponibles dans le commerce, sont discutées.

Mots-clés : appariement climatique / dispersion / invasif / ornemental / poeciliidés

\footnotetext{
*Corresponding author: louisvard@gmail.com
} 


\section{Introduction}

Species invasion is a composite outcome of the interaction of human drivers and natural drivers, with human drivers determining dispersal possibilities and extent, while establishment probabilities and rates are determined by natural drivers (Marchetti et al., 2004; Lockwood et al., 2005; Ribeiro et al., 2008) at different spatial and temporal scales (Marchetti et al., 2004; Blanchet et al., 2009). There is now a general consensus that human activity is a major vector of the invasion process and, for some authors, the best predictor of invasion success (Lockwood et al., 2005; Colautti et al., 2006; Korsu and Huusko, 2009). At different stages of the invasion process (Moyle and Marchetti, 2006), non-indigenous species have to overcome several barriers (biotic and abiotic) in order to invade successfully a new area. The first two steps of this process are "the arrival stage" of the species to the invading ecosystem through anthropogenic transport, and its "survival" throughout it (Sakai et al., 2001; Moyle and Marchetti, 2006). Thus, when suitable ecological conditions and habitats for a species do exist at a large scale, non-native range expansion may be constrained by the limited possibility of anthropogenic transport and thus entry into new aquatic systems. Yet, the quantification of human influences on freshwater fish invasions remains a challenge, due to the lack of effective indicators to express the degree of human activity (GarcíaBerthou, 2007). In order for a non-indigenous species to become resident into a novel environment, propagule pressure is critical in determining which introductions are going to lead to establishment (Marchetti et al., 2004). High propagule pressure usually, but not always, leads to high success rates of colonization (Moyle and Marchetti, 2006) and the establishment of a viable, self-sustaining population (Sakai et al., 2001). Finally, spread and integration are local processes, conditioned by the interplay between abiotic and biotic factors (Moyle and Marchetti, 2006).

Mollies, members of the genus Poecilia (family Poecilidae), are small and short-lived livebearing fishes of the New World with a distribution range from the southern United States to Central America (Meffe and Snelson, 1989; Simpson et al., 2015). They occupy temperate and tropical zones and exploit a broad array of aquatic habitats (Meffe and Snelson, 1989). Some species or their hybrids are popular ornamental fish, and their association with human mechanisms of transport has resulted in numerous introductions worldwide (FAO, 2010; Froese and Pauly, 2014). The sailfin molly Poecilia latipinna (Lesueur, 1821) is the species with the northernmost native distribution range of all species of the genus. It is endemic to the eastern coastline of North America, from North Carolina, through the east coast of Florida to the Gulf of Mexico (Meffe and Snelson, 1989). Due to its popularity as an ornamental fish, but also in the assumption that it is an effective biocontrol agent for preventing malaria by preying on mosquito larvae, the sailfin molly has been introduced throughout the world (Courtenay and Meffe, 1989) with 13 country-level introductions reported in the DIAS database (FAO, 2010) and 17 introductions reported in the Fishbase (Froese and Pauly, 2014). In Europe, and the wider Mediterranean area, the only known population of the sailfin molly has been reported in Greece (Lake Vouliagmeni), originally attributed mistakenly to $P$. sphenops (Chintiroglou et al., 1996). Chintiroglou et al. $(2004,2008)$ refrained from naming this taxon and referred to it as a member of the subgenus Mollienesia (Mollienesia sp.). In subsequent publications, Koutsikos et al. (2012) and Barbieri et al. (2015) referred to this taxon as a sailfin molly, P. latipinna. A recent study (Koutsikos et al., 2017) provided a definite taxonomic identification of this molly population as sailfin molly, based on morphological characters.

Aspects of the life-history, biology and ecology of the sailfin molly in its native habitats have been described in several studies (Snelson, 1980; Felley and Daniels, 1992; Trexler et al., 1992; Nordlie, 2006). Briefly, it is a small ovoviviparous species (maximum size $12.5 \mathrm{~cm}$ ) that feeds principally on algal material (Chick and Mlvor, 1997) and typically lives up to three years. Its short generation time promotes resilience, with minimum population doubling time being less than 15 months (Froese and Pauly, 2014). It prefers hard, alkaline waters and thrives in warm brackish wetlands; however, it is euryhaline and can tolerate salinities from freshwater to $80 \%$ (Nordlie et al., 1992). It is extremely tolerant to oxygen deprivation (Timmerman and Chapman, 2004; Nordlie, 2006) with an ability to withstand pollution, frequently becoming the dominant species when introduced in very disturbed aquatic habitats (Felley and Daniels, 1992; Gonzales and Moran, 2005). It is among the few species that has been adapted to, and even thrive in, sulfidic habitats which are toxic for most metazoans (Riesch et al., 2015).

Though sailfin molly is typically considered a warm-water species (Corfield et al., 2008; Froese and Pauly, 2014), it exhibits a fairly broad thermal tolerance, ranging from 4.0 to $40.0^{\circ} \mathrm{C}$ (Nordlie, 2006; Fischer and Schlupp, 2009). However it appears to be stenothermic in respect to breeding temperature requirements (above $22^{\circ} \mathrm{C}$; Dawes, 1991). Its native distribution extends to an area that spans subtropical latitudes (such as Florida, with $C f a$ type in Köppen-Geiger climate classification, Peel et al., 2007); consequently, it has been suggested that temperature is the limiting factor that largely determines its native geographic range (Dill and Cordone, 1997). However, established populations occur also in California that has a Mediterranean-type climate (Dill and Cordone, 1997). This raises some doubt about the role of temperature as the main limiting factor to its invasions. Temperature alone cannot explain the poor representation of the sailfin molly in European waters, especially around the Mediterranean, where summer temperature in some areas would allow at least a seasonal reproduction (Kalous et al., 2015; Perdikaris et al., 2016). Moreover, photoperiod and salinity are critical environmental factors affecting the life and reproductive traits of poeciliids (Baird, 1974; Meffe and Snelson, 1989; Martin et al., 2009). They are also affected by the synergetic effects of temperature and photoperiod, which in general change concurrently (Vinagre et al., 2009). The relationship between photoperiod and latitude is well illustrated for the biological cycles of various organisms (Lee, 1970). Finally, seasonality, as well as overcast, also interact with photoperiodic cycles, varying latitudinally (Francis, 1970; Lehner, 1987).

An important question in invasion biology is thus whether large-scale climatic factors constitute the main determinant of establishment success (and therefore can provide a good 
indication of potential establishment in a new area) or local habitat characteristics are of greater importance. Relevant literature shows that in general, established sailfin molly populations show consistent associations with warm lentic or slow-flowing lotic habitats that provide an abundant vegetative food resource (salt marshes, estuaries and nearby marine areas, slow-moving portions of rivers and quiet lowland streams, canals and backwaters, and geothermally-heated wetlands). For example, the sailfin molly is extremely abundant and by far the dominant fish species in the warm, brackish and weedy AlHammar marsh of Iraq (Hussain et al., 2009), in the heavily polluted by sewage and agriculture effluents Wadi Haneefah Stream in Saudi Arabia (Al-kahem et al., 2007), in ponds and other stillwater habitats in Hawaii (Englund 2000), and hotspring-fed pools and wetlands in Nevada (Scoppettone et al., 2005), New Zealand (McDowall, 1999, 2006), Canada (Nelson and Paetz, 1992) and Greece (Koutsikos et al., 2017). These examples indicate that the sailfin molly is conservative with respect to its ecological requirements and can only tolerate conditions for which it is evolutionarily experienced.

The aim of this study was to evaluate the current distribution and potential establishment of the sailfin molly worldwide, with emphasis on Europe and the Mediterranean, by exploring climatically suitable areas available to the sailfin molly in different target regions, through the use of climate matching. The concentration (albeit fragmented) of its established populations in tropical and subtropical zones and the pattern of their spatial clustering are discussed, as well as possible agents impeding its establishment in Europe and the Mediterranean, such as low introduction effort and genetic constraints associated with domestication. The role of favorable local environmental conditions that may enable the species' establishment, despite climate mismatch, is also explored.

\section{Materials and Methods}

To map the distributional range of the sailfin molly and to evaluate the relative contribution of the invasive spread drivers, worldwide occurrence records of the species were obtained from two sources. The first source of information was scientific publications (scientific articles, books, conference proceedings, doctoral and master theses); however, a common and significant obstacle for obtaining distributional data of alien fish is that they are not easily accessible, since in many occasions when introductions occur, they are either poorly known or when they are reported, the data are not always available. To overcome these limitations we extended our publication review to include references from technical reports. Another source of information was online databases, namely, CABI - Invasive Species Compendium (CABI, 2014), DAISIE - Delivering Alien Invasive Species Inventories for Europe (DAISIE, 2008), DIAS - Database on Introductions of Aquatic Species (FAO, 2010), FishBase (Froese and Pauly, 2014), IUCN/SSC Invasive Species Specialist Group (Global Invasive Species Database, 2015), and NAS - Nonindigenous Aquatic Species USGS (Nico et al., 2014).

In order to assess the establishment status of a sailfin molly population in the current study the following criteria were used: a population was recorded as "established" when this population was explicitly registered as such in at least one source. A population was recorded of "unknown status" when there was only a single reference to the presence of the species. A population was recorded as "probably established" when it was referred as such in at least one scientific source and/or there were multiple references to its presence at a specific location. When comparing the establishment status of the three Poecilia species in Europe, a fourth category "probably not established" is used, when it was referred as such in at least one scientific source.

We applied the Climatch v.1.0 (Bureau of Rural Sciences, 2008) in order to compare the climate match between the native geographic range of the sailfin molly (source area) and four different target areas: (a) validated introductions of the target species on a global scale, (b) potential areas of invasion worldwide, (c) potential areas of invasion in the European continent and (d) potential areas of invasion in the Mediterranean region. For the imported occurrence records of validated introductions, Climatch automatically selected 100 of the nearest available meteorological stations to those listed in the location file. The other three target areas utilised data from 19,000, 1,753 and 240 climatic stations respectively, of the WorldClim project database (Hijmans et al., 2005).

The ecological requirements of freshwater fishes are primarily related to temperature and hydrology (Matthews, 1998). Hence, climatic matching conditions were represented in the current study by the following variables: "Annual mean temperature", "Temperature during the coldest quarter of the year", and "Mean annual rainfall" for the accurate investigation of the potential spread of the evaluated species within the target areas (Costa and Schlupp 2010; Kalous et al., 2015; Kotovska et al., 2016; Patoka et al., 2017), with an Euclidean algorithm. The first two variables were used in order to represent temperature requirements, while the third one was applied as a key component of the hydrological cycle, as well as for its correlation to salinity and photoperiod, tightening up further the climate-matching function. Climate-match values range from 10 to 0 , wherein 10 stands for the highest-level match and 0 for the poorest match. Values that equal or are higher than 7.0 indicate that temperature is not an environmental barrier to survival.

\section{Results}

\subsection{Current distribution}

The non-native distribution of the sailfin molly can be characterised as global but highly fragmented (Fig. 1). We positively validated 100 non-native occurrence records worldwide (see supplementary Tab. S1 and Tab. S2 that provide relevant information on non-native occurrences by continent and site details respectively). Of the 100 validated introductions worldwide, 80 populations are confirmed "established" and 14 "probably established", while the status of the remaining six is unknown (Fig. 1). More than half (60 occurrence records) are located in the American continent (51 established populations). Most validated introductions in this continent fall within the south-western part of the United States (41 occurrences), characterised by Mediterranean-type climate conditions (Fig.1, Tab. S1, S2).

In the other continents, the occurrence of the species is sporadic with the introduced populations sparsely distributed 


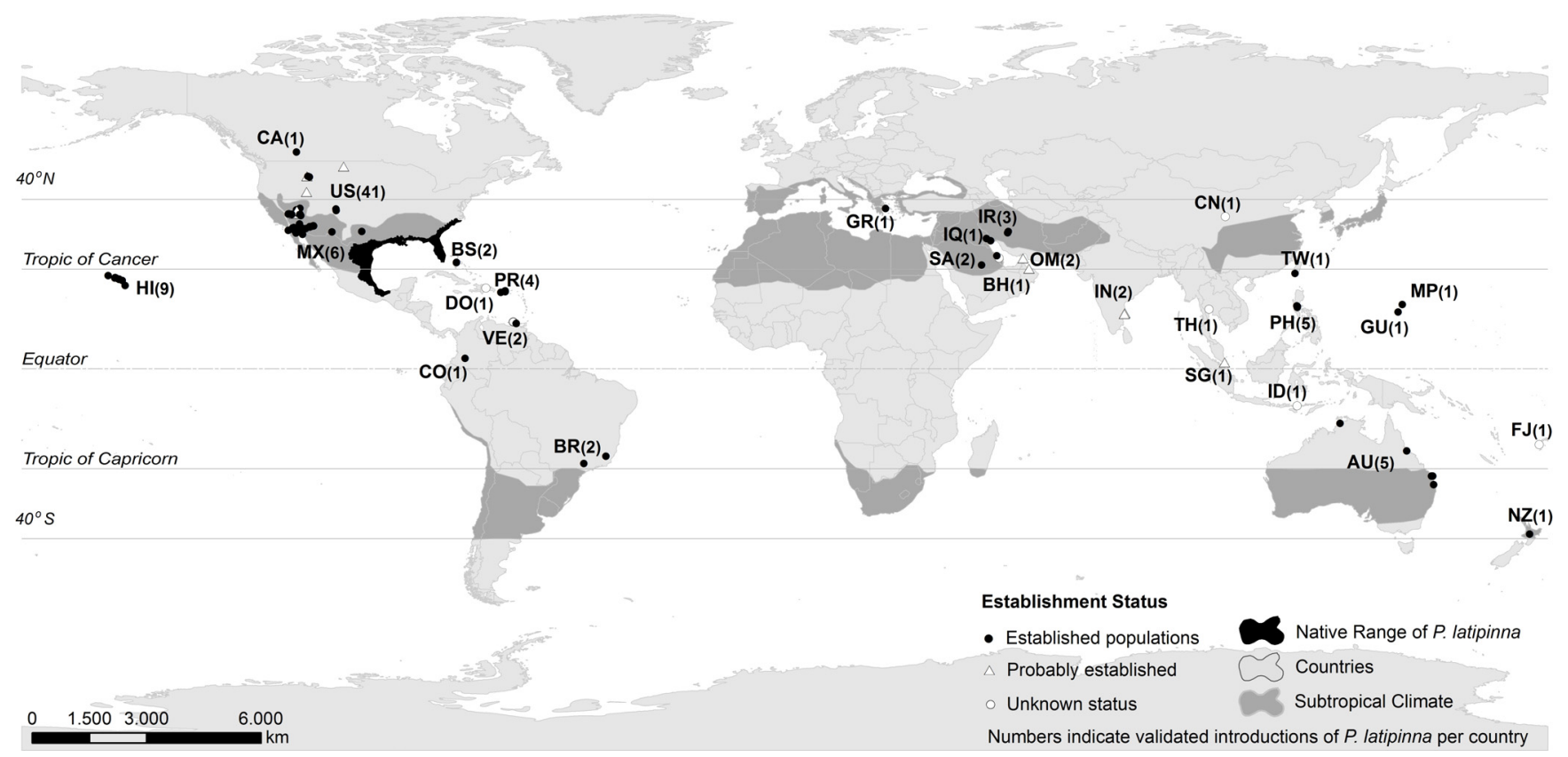

Fig. 1. The global distribution of validated introductions of the sailfin molly (Poecilia latipinna) with establishment status noted. AU: Australia, BS: Bahamas, BH: Bahrain, BR: Brazil, CA: Canada, CN: China, MP(US): Commonwealth of the Northern Mariana Islands, CO: Colombia, DO: Dominican Republic, FJ: Fiji, GR: Greece, GU: Guam, HI(US): Hawaii, IN: India, ID: Indonesia, IQ: Iraq, IR: Iran, MX: Mexico, NZ: New Zealand, OM: Oman, PK: Pakistan, PH: Philippines, PR: Puerto Rico, SA: Saudi Arabia, SG: Singapore, TH: Thailand, TW: Taiwan, US: USA, VZ: Venezuela.

and highly fragmented. There have been 23 validated introductions (13 established populations) in Asia (with several around the Persian Gulf) and 16 introductions (15 established populations) in Oceania (Fig. 1, Tab. S1, S2). There are no validated introductions in Africa. Three previous reports in Kenya were proved misidentifications (see Seegers et al., 2003). Finally, there is only one validated introduction in Europe, of an established population at the geothermal Lake Vouliagmeni (Attica, southern Greece, Fig. 1, Tab. S1, S2).

The absence of established sailfin molly populations in Europe, except the one in Greece, contrasts sharply with the occurrence of two other closely related and ecologically similar poeciliids, the guppy $P$. reticulata Peters, 1859 and the shortfin molly P. sphenops Valenciennes, 1846, which have been reported from 18 and six European localities respectively (Tab. 1).

\subsection{Potential establishment of the sailfin molly through climate match}

The climate match map of validated introductions of the sailfin molly on a global scale (Fig. 2a, Tab. 2) showed that $62 \%$ of the meteorological sites matching validated populations scored $\geq 7.0$, indicating no environmental barrier to establishment. A small proportion (9\%) indicated a very low probability of establishment of the species (climatch scores $0-1)$. The respective localities, all in Northern US and Canada, are all wetland habitats associated with hot springs in areas with otherwise adverse climatic conditions for the species' survival (Fig. 2a), with the favorable local conditions possibly enabling the support of populations despite climate mismatch.
Worldwide, the climate match map indicated no environmental barrier to survival for $28 \%$ of the localities assessed (score $\geq 7.0$, Tab. 2, Fig. 2b).

In the European continent, the climate match maps indicated low probabilities of sailfin molly establishment (Fig. 3) but much higher probabilities at localities around the Mediterranean (Fig. 4). Specifically, on the European continent, the probability of establishment of the sailfin molly was $5 \%$ (Climatch scores $\geq 7.0$ ). Conversely, in the Mediterranean Basin, climatic conditions were more suitable for its establishment, with $60 \%$ of the meteorological sites indicating scores $\geq 7$ of the Climatch scores (Tab. 2).

\section{Discussion}

\subsection{Non-indigenous distribution patterns of sailfin molly}

The global distribution pattern of the sailfin molly outside its native range points to temperature as the dominant ecological factor influencing the probability of establishment. Indeed, most validated introductions were recorded from tropical and subtropical regions. In temperate climatic zones, the occurrence of the species appears to be rare and highly localized. In fact, the majority of recorded sailfin molly occurrences outside the subtropical belt are in small geothermally heated water bodies. Evidently, specific local conditions may create pockets of environmental suitability, allowing the species to overcome the climate barrier to establishment (Scoppettone et al., 2005). Costa and Schlupp 
Table 1. Reported occurrences of Poecilia latipinna, P. reticulata and P. sphenops in Europe.

\begin{tabular}{|c|c|c|c|c|}
\hline Countries & P. latipinna & P. reticulata & P. sphenops & Reference \\
\hline Albania & & U & & {$[4,7,9,13,20]$} \\
\hline Austria & & & & {$[5,10]$} \\
\hline Bulgaria & & $\mathrm{U}$ & & [20] \\
\hline Czech & & $+1-$ & - & {$[7,9]$} \\
\hline France & & $\mathrm{U}$ & - & {$[12]$} \\
\hline Germany & & 0 & $\mathrm{U}$ & {$[11,15]$} \\
\hline Greece & 0 & & & [16] \\
\hline Hungary & & + & 0 & {$[7,9]$} \\
\hline Ireland & & $\mathrm{U}$ & & [12] \\
\hline Italy & & - & + & {$[7,9,19]$} \\
\hline Netherlands & & 0 & & {$[5,7,9,15]$} \\
\hline Poland & & - & & [17] \\
\hline Romania & & 0 & 0 & {$[5,13,18]$} \\
\hline Russia & & 0 & & {$[2,9,13,15]$} \\
\hline Serbia & & 0 & & [20] \\
\hline Slovakia & & 0 & - & {$[7,9,13,14]$} \\
\hline Spain & & + & & {$[3,6,7,8,15]$} \\
\hline UK & & 0 & & {$[5,7,9,21]$} \\
\hline Ukraine & & - & & [1] \\
\hline Occurrence & 1 & 18 & 6 & - \\
\hline
\end{tabular}

$=$ Established, $+=$ Probably established, $-=$ Probably not established, $\mathrm{U}=$ Unknown

(1) Alexandrov et al., 2007, (2) Budaev, 1997, (3) Cobo et al., 2010, (4) Crivelli, 1995, (5) DAISIE, 2008, (6) Dhora, 2010, (7) Elvira, 2001, (8) Elvira and Almodovar, 2001, (9) Froese and Pauly, 2014, (10) Füreder and Pöckl, 2007, (11) Geiter et al., 2002, (12) Global Invasive Species Database 2015, (13) IMPASSE, 2007, (14) Koščo et al., 2010, (15) Kottelat and Freyhof, 2007 (16) Koutsikos et al., 2017, (17) Nowak et al., 2008, (18) Petrescu-Mag et al., 2008, (19) Piazzini et al., 2010, (20) Piria et al., 2018, (21) Zieba et al., 2010.

(2010) used abiotic variables from known occurrence localities of the sailfin molly to model its potential distribution in South and East United States. They asserted that minimum temperature of the coldest month is the factor best explaining establishment success; however, they noted that large-scale climatic features may not sufficiently explain the presence of the species at some locations (e.g. in central Texas).

Another distribution pattern evident from our data is the spatial clustering of many introduced sailfin molly populations with a human relevance. More specifically, higher occurrence frequencies are observed in regions close to the native area of the species, such as in the southwestern US, where it has been established in five states (CABI, 2014), as well as in certain Caribbean islands. This clustering seems to be humanmediated, rather than having an ecological basis, and it is likely to reflect differences in introduction rates. Ornamental fish trade may be a major vector of introduction within the more urbanized southwestern US, since there is a flourishing ornamental fish production industry in the state of Florida which accounts for approximately $95 \%$ of all ornamental fish produced in the U.S.A. (Hill and Yanong, 2002). Outside the US, relatively high occurrence frequencies were noted around major centers of ornamental fish production and trade, as in the islands of the south-western Pacific. Some non-native occurrences have been attributed to its intentional release as a biocontrol agent for malaria, such as in the islands of the central Pacific (for Hawaii see Englund, 1999) and possibly in countries around the Persian Gulf, though at a much smaller scale than mosquitofishes (Arthington and McKenzie, 1997; Lintermans, 2004). However, the release of poeciliids by hobbyists as a vector of introduction in rapidly developing countries bordering the Persian Gulf cannot be excluded (Esmaeli et al., 2017).

\subsection{Potential agents impeding sailfin molly establishment in Europe and the Mediterranean}

The results from the current study indicate that temperature is the dominant ecological factor influencing the probability of sailfin molly establishment globally. The low representation of the sailfin molly in the Mediterranean area cannot, however, be solely attributed to climatic constraints, as it runs contrary to the predictions of the Climatch tool, which indicated a $60 \%$ suitability of the climatic conditions for establishment in this region. It is well established that the sailfin molly is a tolerant species with broad limits to a number of habitat factors (Marchetti et al., 2004). Indeed, habitat descriptions in its native distributional range indicate strong preference to alkaline and brackish waters and rich submerged vegetation (Nordlie et al., 1992). In the course of the current study, a bibliographic search was conducted to retrieve data on additional environmental factors (e.g. vegetation cover, flow values, alkalinity) that possibly affect the establishment of sailfin molly; however, available data on habitat conditions in the introduced areas were extremely limited. Nevertheless, the specific habitat requirements of the sailfin molly appear to limit the amount of habitat that is suitable for the species, even in thermally-suitable areas. Thus, scarcity of suitable habitat (e.g. lentic systems) and trophic conditions (e.g. vegetative food supply), could account, at least partially, for the unexpectedly low occurrence frequency of the sailfin molly in Europe and the Meditteranean.

Overall, cold intolerance and release to unfavorable habitat environments may preclude widespread establishment of the sailfin molly, as well as of the shortfin molly and the guppy, in European waters. However, it is reasonable to expect the establishment probabilities of the sailfin molly to be higher than that of the other two species, as the former occurs naturally at higher latitudes and has lower thermal tolerance ranges than the other two poeciliids (Dill and Cordone, 1997).

Apart from ecological factors, propagule pressure and various other types of human involvement (e.g. breeding practices) may affect the invasion process or may confound interpretations of invasion patterns. Holčík (1991) and Maceda-Veiga et al., (2013) indicated that the guppy, and to a lesser degree the shortfin molly, are more commonly traded as ornamental fish in Europe, compared to the sailfin molly. Indeed, a recent study assessing the availability of ornamental species in Greece (Papavlasopoulou et al., 2013) indicated that $P$. reticulata had a $>50 \%$ frequency of presence in Greek aquarium stores, while the presence of sailfin molly in pet stores was lower than $50 \%$. Thus, a "lower release rate" explanation, i.e. that the frequency differences in establishment success stem from introduction effort differences rather than from ecological constraints, is also likely. It is known that 
a

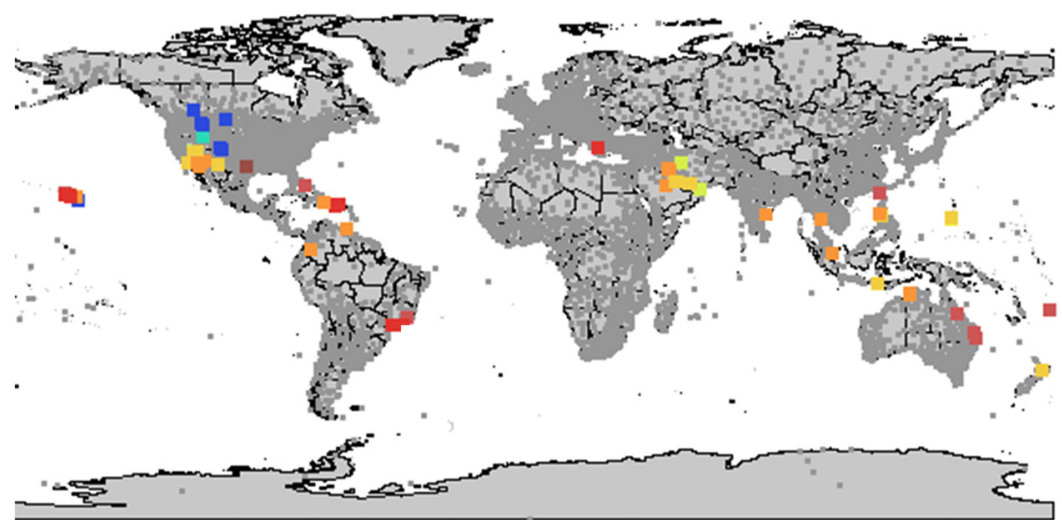

Algorithm: Euclidean

b

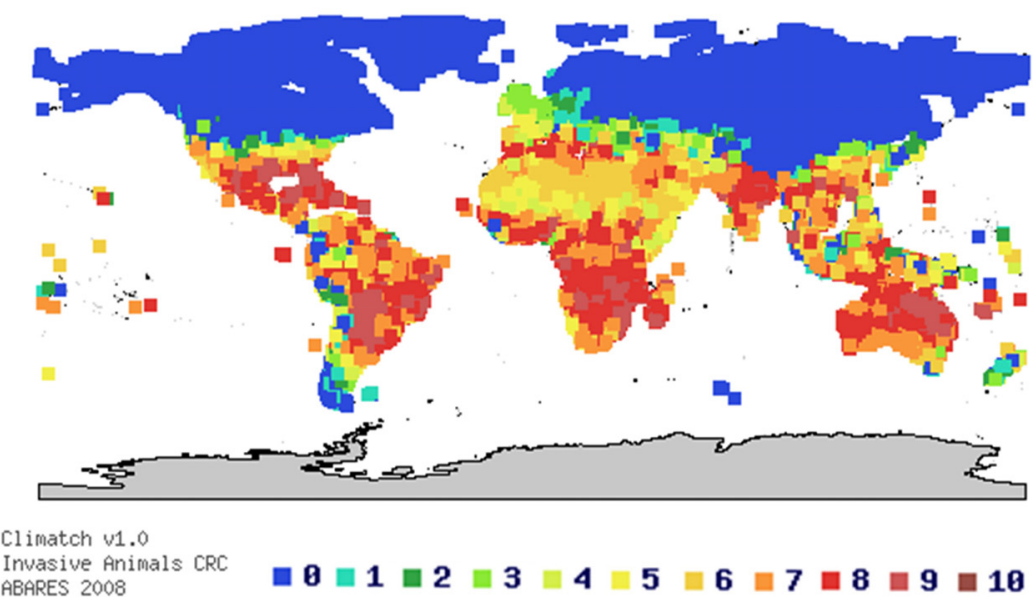

Fig. 2. (a) Climate match map of validated introductions of the sailfin molly (Poecilia latipinna) on a global range; (b) Climate match map of areas with probability of establishment for the sailfin molly worldwide. Scores of $\geq 7.0$ are interpreted as indicating no environmental barrier to survival.

releasing unwanted pet fishes is the main invasion pathway of ornamental fish (Semmens et al., 2004; Copp et al., 2007; Krishnakumar et al., 2009). Under the assumption that the most popular and frequently traded fish have more opportunities to be released, trade data may be used as a surrogate for introduction effort (Rixon et al., 2005; Gertzen et al., 2008). Rixon et al. (2005) measured the frequency of occurrence of ornamental fish species in a number of pet stores in Canada and the US and showed that, among poeciliids, the guppy had a higher frequency $(95 \%)$ than the sailfin molly $(80 \%)$ and the shortfin molly $(75 \%)$. These may explain, at least partially, the highest number of European localities hosting feral guppy rather than sailfin and shortfin molly populations.

Other explanations for the poor establishment rate of the sailfin molly in Europe may be related to taxonomic ambiguities. This is evident in previous misidentifications of Poecilia species, as in the case of the Lake Vouliagmeni sailfin molly in Greece (Chintiroglou et al., 1996; see also Dill and Cordone 1997 for $P$. sphenops confused with $P$. latipinna). Poeciliids have a complex taxonomy (Breden et al., 1999), which is further complicated by the ease of interspecific hybridization (Kittell et al., 2005).

The differential vulnerability of colour morphs to several predators (carnivorous fishes, water snakes, birds etc.) can be invoked as an additional explanation for its poor establishment success in Europe. Finally, reduced reproductive or physical fitness due to breeding manipulations, and/or of long-fin males' gonopodium, may also explain the low establishment rate of the sailfin molly in Europe. Commercial strains of sailfin molly are becoming progressively a fusion of various origins that include artificially selected breeds and crosses with other molly species (Fossa, 2004; Koutsikos et al., 2017) that may be sterile, or have offspring with reduced capacity for survival and sustained reproduction (Rodionova et al., 1996; Lampert et al., 
Table 2. Climatch scores for globally validated introductions, and for areas with probability of sailfin molly Poecilia latipinna establishment worldwide, European and peri-Mediterranean scale. Scores of $\geq 7.0$ (marked in grey) are interpreted as indicating no environmental barrier to survival.

\begin{tabular}{ccccc}
\hline Climatch Score & Global introductions & Worldwide & European continent & Mediterranean region \\
\hline $\mathbf{0}$ & 8 & 9386 & 1106 & 2 \\
$\mathbf{1}$ & 1 & 372 & 114 & 9 \\
$\mathbf{2}$ & 0 & 381 & 128 & 5 \\
$\mathbf{3}$ & 0 & 437 & 141 & 9 \\
$\mathbf{4}$ & 4 & 550 & 89 & 7 \\
$\mathbf{5}$ & 2 & 870 & 64 & 28 \\
$\mathbf{6}$ & 22 & 1730 & 32 & 69 \\
$\mathbf{7}$ & 34 & 1875 & 28 & 57 \\
$\mathbf{8}$ & 18 & 2308 & 43 & 14 \\
$\mathbf{9}$ & 10 & 1091 & 8 & 0 \\
$\mathbf{1 0}$ & 1 & 0 & 0 & $\mathbf{2 4 0}$ \\
\hline
\end{tabular}

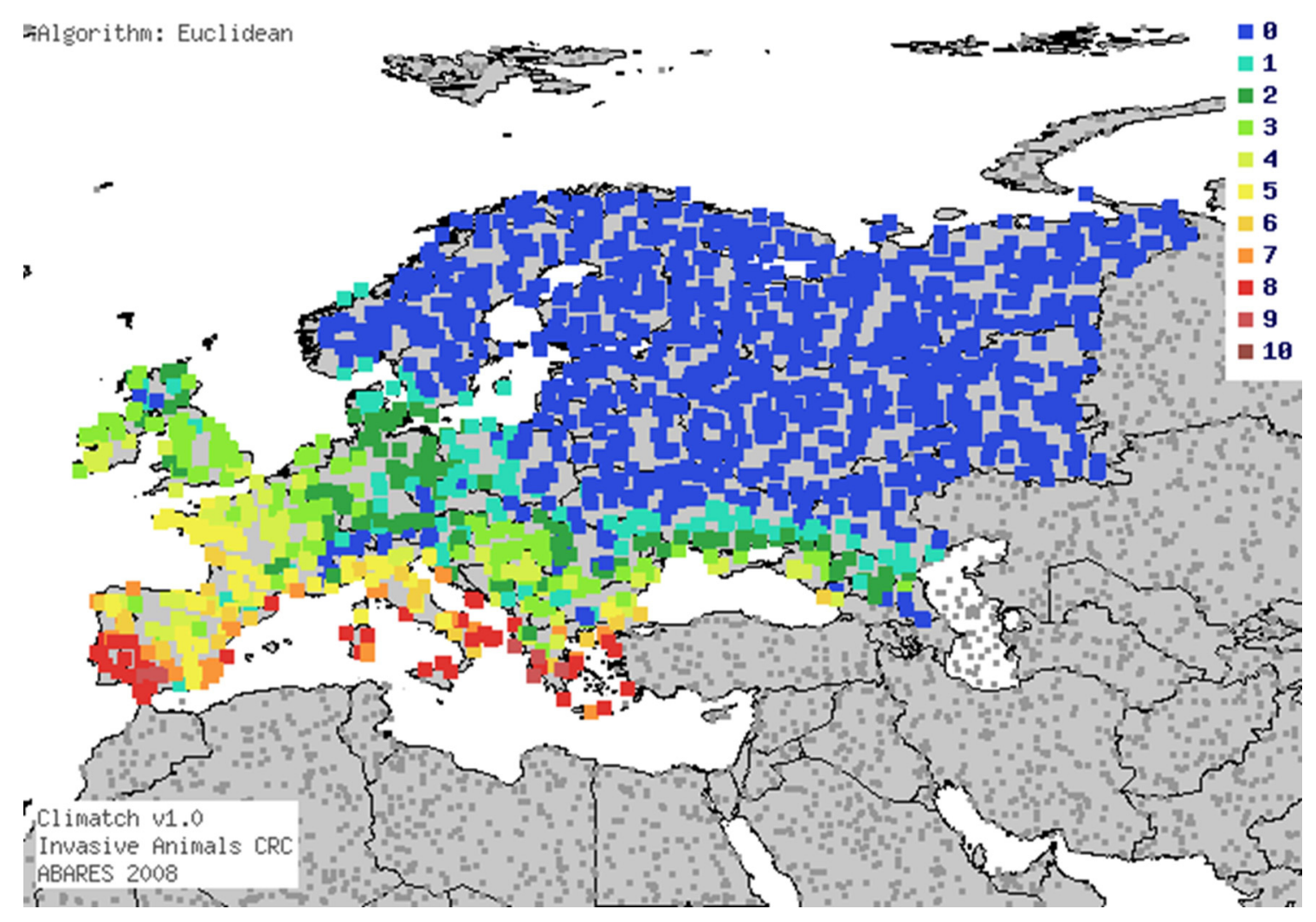

Fig. 3. Climate match map showing areas with probability of establishment for the sailfin molly (Poecilia latipinna) in Europe.

2007). Artificial selection aims for improved ornamental traits, and often disrupts the stabilised biological systems that ensure normal development or the ability to survive and reproduce under harsh environmental conditions. It is notable in this context that the Vouliagmeni sailfin molly population in Greece represents a relatively old introduction (early 1960's; Koutsikos et al., 2017) before hybridisation became a widespread practice in ornamental fish production. The same is also evident for the establishments in Iraq, Hawaii and Texas (US) in the early 20th century (Kennedy, 1937; Englund, 1999;
Costa and Schlupp, 2010), as well as in Australia, Canada, Nevada and California's Salton Sea (US) in the late 1960's (Nelson and Paetz, 1992; Scoppettone et al., 2005; Corfield et al., 2008; Martin and Saiki, 2009).

\subsection{Potential establishment and impacts on native biodiversity}

The current study has shown that the probability of establishment of the sailfin molly globally was moderate 


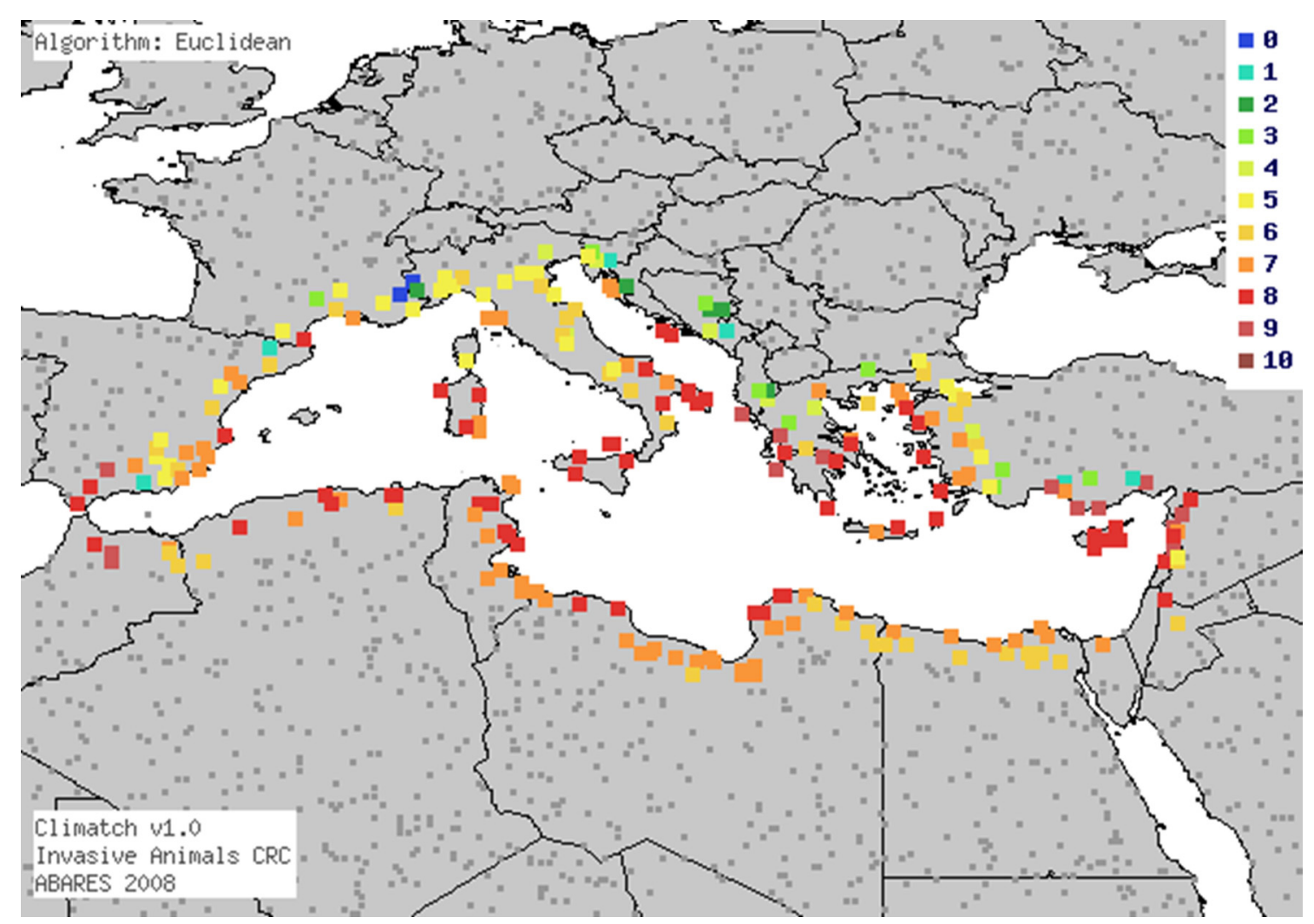

Fig. 4. Climate match map showing areas with probability of establishment for the sailfin molly (Poecilia latipinna) in the peri-mediterranean region.

$(\sim 30 \%)$ and confined to the subtropics, where currently most of the species' established populations are located. Bomford and Glover (2004) and Bomford (2008) asserted "very high" and "extreme" establishment risks for the sailfin molly in Australian and New Zealand waters, using a combination of variables, including climate match and history of establishment elsewhere. One of the most commonly used variables is the "previous establishment success rate", estimated as a proportion of successful introductions to the total number of introductions made in other regions. However, the use of such a variable may overestimate the invasion risk, when establishment failures are poorly documented. This could be the case for the sailfin molly, when assessed with this method, as there are practically no records of failed introductions for this species, except from the USA and New Zealand (Nico et al., 2014; McDowall, 1999).

According to Gozlan et al. (2010), the majority of ornamental fishes have very low probabilities of invading Europe due to their ecological and physiological requirements. However, a recent Fish Invasiveness Screening Kit (FISK) evaluation for several ornamental fishes (Kalous et al., 2015), showed that a number of locations within southern Europe are climatically matched to their native areas. In the current study, the probability of establishment of the sailfin molly on the European continent was generally very low (below 7\%). It is highly possible that failed sailfin introductions have repeatedly occurred in Europe, mostly pet releases in unsuitable habitats. However, the data are anecdotal, or the introductions remain unrecorded. Overall, the risk of invasion spread of the sailfin molly in Europe is assessed to be limited due to various reasons, discussed above, as also evident by our Climatch data, despite probably high release rates. In the Mediterranean Basin, in contrast, our data indicated that climatic conditions are more suitable for the species' establishment, with no environmental barrier to survival to almost $60 \%$ of the assessed sites in the periMediterranean countries. Indeed, Perdikaris et al. (2016) ranked the invasion risk of the sailfin molly in Greece as being moderately high by applying FISK. These results highlight the importance of rigorous surveying of those lentic habitats that fulfill the species' habitat requirements, with special focus on urban ponds and lakes, as potential release sites by hobbyists.

Ornamental poeciliids have been repeatedly blamed for adverse impacts on native fish communities and other biota (Englund et al., 2000; NACA, 2005; Corfield et al., 2008). On the basis of published data reporting adverse ecological impacts of introduced species, the sailfin molly has been identified as one of the top 18 species with adverse ecological effects (Casal, 2006), and is classified among the 14 most invasive ornamental fish species (Froese and Pauly, 2014). Possible effects of the sailfin molly on other native fauna and other elements of the biota are expected to be mainly indirect, e.g. effected through food web alterations or non-native disease transmission (Arthur and Lumanlan-Mayo, 1997), as the species is a non-aggressive fish, feeding primarily upon algae and detritus and thus apparently not interacting trophically with conspecifics. For instance, Kryss et al. (2008) have assessed that Poecilia sp. hybrids introduced in 
Hawaiian waters have been the source of parasites that now infest native gobies and have also impacted the water quality of coastal ecosystems. It should be the aim of future studies to evaluate the nature and magnitude of environmental impacts caused by sailfin molly introductions.

Acknowledgements. The authors wish to thank J. Patoka and the anonymous reviewer for greatly improving the manuscript through their comments. They would also like to thank B. Zimmerman for proofreading the English text and C. Perdikaris for his comments on the manuscript. This research forms a part of the PhD dissertation by N. Koutsikos at the Department of Environment, University of the Aegean, Greece.

\section{References}

Al-kahem HF, Al Ghanim KA, Ahmad Z. 2007. Studies on feeding of Sailfin Molly (P. latipinna) dwelling in Wadi Haneefah stream, Riyadh, Kingdom of Saudi Arabia. Pakistan. J Biol Sce 10: 335341.

Alexandrov B, Boltachev A, Kharchenko T, Lyashenko A, Son M, Tsarenko P, Zukinsky V. 2007. Trends of aquatic alien species invasions in Ukraine. Aquat Invasions 2: 215-242.

Arthington A, McKenzie F. 1997. Review of impacts of displaced/ introduced fauna associated with inland waters. Australia: State of the Environment Technical Paper Series (Inland Waters). Department of the Environment, Canberra, Australia, 69 p.

Arthur JR, Lumanlan-Mayo S. 1997. Checklist of the parasites of fishes of the Philippines. Fish. Tech. Pap. 369. FAO, Rome, 102 p.

Baird RC. 1974. Aspects of social behavior in Poecilia latipinna (Lesueur). Rev Biol Trop $21:$ 399-416.

Barbieri R, Zogaris S, Kalogianni E, Stoumboudi MT, Chatzinikolaou Y, Giakoumi S, Kapakos Y, Kommatas D, Koutsikos N, Tachos V, Vardakas L, Economou AN. 2015. Freshwater Fishes and Lampreys of Greece: An annotated checklist. Monographs on Marine Sciences No. 8. Athens, Greece: Hellenic Centre for Marine Research, $130 \mathrm{p}$.

Blanchet S, Leprieur F, Beauchard O, Staes J, Oberdorff T, Brosse S. 2009. Broad-scale determinants of non-native fish species richness are context-dependent. Proc R Soc B 276: 2385-2394.

Bomford M. 2008. Risk assessment models for establishment of exotic vertebrates in Australia and New Zealand. Invasive Animals Cooperative Research Centre, Canberra, Australia $191 \mathrm{p}$.

Bomford M, Glover J. 2004. Risk Assessment Model for the Import and Keeping of Exotic Freshwater and Estuarine Finfish. Bureau of Rural Sciences, Canberra, Australia 125 p.

Breden F, Ptacek MB, Rashed M, Taphorn D, Figueiredo CA. 1999. Molecular phylogeny of the live-bearing fish genus Poecilia (Cyprinodontiformes: Poeciliidae). Mol Phylogenet Evol 12: 95104.

Budaev SV. 1997. "Personality" in the Guppy (Poecilia reticulata):A Correlational Study of Exploratory Behavior and Social Tendency. J Comp Psychol 111: 399-411.

Bureau of Rural Sciences. 2008. Climatch v1.0 software. Bureau of Rural Sciences, Department of Agriculture, Fisheries and Forestry, Canberra, Australia. Available online: http://adl.brs.gov.au:8080/ Climatch/climatch.jsp. [Accessed: 18/05/2017].

CABI. 2014. Poecilia latipinna [Maddern M.]. Invasive Species Compendium. Wallingford, UK: CAB International. http://www. cabi.org/isc/datasheet/68203 [Accessed: 17/06/2014].

Casal CMV. 2006. Global documentation of fish introductions: the growing crisis and recommendations for action. Biol Invasions 8: $3-11$.
Chick JH, Mlvor CC. 1997. Habitat selection by three littoral zone fishes: effects of predation pressure, plant density and macrophyte type. Ecol Freshwat Fish 6: 27-35.

Chintiroglou CC, Antoniadou C, Damianidis P, Diapoulis A. 2004. Contribution to the knowledge of the macrobenthic biodiversity of Vouliagmeni Lagoon (Attica, Greece). CIESM 37: 506-506.

Chintiroglou CC, Antoniadou C, Damianidis P. 2008. Spatiotemporal variability of zoobenthic communities in a tectonic lagoon (Lake Vouliagmeni, Attika, Greece). J Mar Biol Assoc UK 88: 873-881.

Chintiroglou CC, Valkouma Th, Culley M. 1996. Allometry of feeding and body size in a population of the sea anemone Paranemonia vouliagmeniensis. J Mar Biol Assoc UK 76: 603-616.

Cobo F, Vieira-Lanero R, Rego E, Servia MJ 2010. Temporal trends in non-indigenous freshwater species records during the 20th century: a case study in Iberian Peninsula. Biodivers Conserv 19: 3471-348.

Colautti RI, Ricciard A, Grigorovich IA, MacIsaacet HJ. 2006. Is invasion success explained by the enemy release hypothesis? Ecol Lett 7: 721-733.

Copp GH, Templeton M, Gozlan RE. 2007. Propagule pressure and the invasion risks of non-native freshwater fishes in Europe: a case study of England. J Fish Biol 71: 148-159.

Corfield J, Diggles B, Jubb C, McDowall RM, Moore A, Richards A, Rowe DK. 2008. Review of the impacts of introduced ornamental fish species that have established wild populations in Australia'. Prepared for the Australian Government Department of the Environment, Water, Heritage and the Arts, Commonwealth of Australia, $277 \mathrm{p}$.

Costa GC, Schlupp I. 2010 Biogeography of the Amazon molly: ecological niche and range limits of an asexual hybrid species. Global Ecol Biogeogr 19: 442-451.

Courtenay WR, Meffe GK. 1989. Small fishes in strange places: a review of introduced Poeciliids. In Meffe GK, Snelson FFJ, eds. Ecology and evolution of livebearing fishes (Poeciliidae), PrenticeHall, Englewood Cliffs, NJ, USA, 319-331.

Crivelli AJ. 1995. Are fish introductions a threat to endemic freshwater fishes in the northern Mediterranean region? Biol Conserv 72: 311-319.

DAISIE. 2008. Poecilia sphenops. European Invasive Alien Species Gateway. http://www.europe-aliens.org/speciesFactsheet.do?spe ciesId=101277\# [Accessed: 22/05/2010].

Dawes JA. 1991. Livebearing fishes: A guide to their aquarium care, biology and classification London, UK: Blandford Publications, $240 \mathrm{p}$.

Dhora, Dh. 2010. Regjistër i specieve të faunës së Shqipërisë. Register of species of the fauna of Albania. Camaj-Pipa, Albania, 208.

Dill WA, Cordone AJ. 1997. History and Status of Introduced Fishes in California, 1871-1996. California Department of Fish and Game, Fish Bulletin 178, Sacramento, California, USA, 414 p.

Elvira, B. (2001). Identification of non-native freshwater fishes established in Europe and assessment of their potential threats to the biological diversity. In: Convention on the conservation of European Wildlife and Natural Habitiats Standing Committee 21st meeting, Strasbourg. http://www.nobanis.org/files/Bern-fish\% 20identification.doc. [Accessed 2/072010].

Elvira B, Almodovar A. 2001. Freshwater fish in Spain: facts and figures at the beginning of the 21st century. J Fish Biol 59: 323 331.

Englund RA. 1999. The impacts of introduced poeciliid fish and Odonata on the endemic Megalagrion (Odonata) damselflies of Oahu Island, Hawaii. J Insect Conserv 3: 225-243. 
Englund RA, Arakaki K, Preston DJ, Coles SL, Eldredge LG. 2000. Nonindigenous Freshwater and Estuarine Species Introductions and their Potential to Affect Sport Fishing in the Lower Stream and Estuarine Regions of the South and West Shores of Oahu, Hawaii. Bishop Museum Technical Report No. 17, Bishop Museum, Honolulu, Hawaii, USA, 121.

Esmaeli HR, Masoudi M, Amini Chermahini M, Esmaeli AH, Zarei F, Ebrahimi M. 2017. Invasion of the Neotropical and Nearctic fishes to Iran. FishTaxa 2: 126-133.

FAO 2010. Database on introduction of aquatic species (DIAS). Food and Agriculture Organization of the United Nations, Rome, Italy.

Felley JD, Daniels GL. 1992. Life history of the sailfin molly (Poecilia latipinna) in two degraded waterways in southwestern Louisiana. Southwest Nat 37: 16-21.

Fischer C, Schlupp I. 2009. Differences in thermal tolerance in coexisting sexual and asexual mollies (Poecilia, Poeciliidae, Teleostei). J Fish Biol 74: 1662-1668.

Fossa SA. 2004. Man-made fish: domesticated fishes and their place in the hobby. Ornamental Fish Int $J$ 44: 1-23.

Francis CA. 1970. Effective day lengths for the study of photoperiod sensitive reactions in plants. Agron J 62: 790-792.

Froese R. Pauly D. 2014. FishBase. World Wide Web electronic publication. [Accessed: 29/06/2014].

Füreder L, Pöckl M. 2007. Ecological traits of aquatic NIS invading Austrian freshwaters. In: Gherardi F, ed., Biological invaders in inland waters: profiles, distribution and threats. Springer, Dordrecht, pp. 233-257.

García-Berthou E. 2007. The characteristics of invasive fishes: what has been learned so far? J Fish Biol 71: 33-55.

Geiter O, Homma S, Kinzelbach R. 2002. Bestandsaufnahme und Bewertung von Neozoen in Deutschland. Umweltbundesamt, $308 \mathrm{p}$.

Gertzen E, Familiar O, Leung B. 2008. Quantifying invasion pathways: fish introductions from the aquarium trade. Can J Fish Aquat Sci 65: 1265-1273.

Global Invasive Species Database. 2015. Poecilia reticulata. IUCN/ SSC Invasive Species Specialist Group. http://www.iucngisd.org/ $\mathrm{gisd} /$ speciesname/Poecilia+reticulata [Accessed: 14/11/2015].

Gonzales M, Moran E. 2005. An inventory of fish species within the San Antonio Missions National Historical Park. San Antonio River Authority, Final Report, $53 \mathrm{p}$.

Gozlan RE, Britton JR, Cowx I, Copp GH. 2010. Current knowledge on non-native freshwater fish introductions. J Fish Biol 76: 751786.

Hijmans RJ, Cameron SE, Parra JL, Jones PG, Jarvis A. 2005. Very high resolution interpolated climate surfaces for global land areas. Int J Climatol 25: 1965-1978

Hill JE, Yanong RPE. 2002. Freshwater ornamental fish commonly cultured in Florida. Circular 54, Institute of Food and Agriculture Sciences, University of Florida, USA, $6 \mathrm{p}$.

Holčík J. 1991. Fish introductions in Europe with particular reference to its central and eastern part. Can J Fish Aquat Sci 48: 13-23.

Hussain NA, Mohamed ARM, Al-Noo SS, Mutlak FM, Abed IM, Coad BW. 2009. Structure and ecological indices of the fish assemblages in the recently restored Al-Hammar Marsh, southern Iraq. BIORISK - Biodiversity and Ecosystem Risk Assessment [Environment, biodiversity and conservation in the Middle East. In: Proceedings of the First Middle Eastern biodiversity congress, Aqaba, Jordan, 20-23 October 2008.], 3: 173-186.

IMPASSE 2007 Environmental impacts of alien species in aquaculture. Sustainable Management of Europe's Natural Resources - Project no.: 044142, Deliverable 1.3. European Commission, 26.
Kalous L, Patoka J, Kopecký O. 2015. European hub for invaders: risk assessment of freshwater aquarium fishes exported from the Czech Republic. Acta Ichthyol Piscat 45 (3): 239.

Kennedy WP. 1937. Some additions to the fauna of Iraq. $J$ Bombay Nat Hist Soc 39: 745-749.

Kittell MM, Harvey MN, Contraras-Balderas S, Ptacek MB. 2005. Wild-caught hybrids between sailfin and shortfin mollies (Poeciliidae, Poecilia): morphological and molecular verification. Hidrobiológica 15: 131-137.

Korsu K, Huusko A. 2009. Propagule pressure and initial dispersal as determinants of establishment success of brook trout (Salvelinus fontinalis Mitchill 1814). Aquat Invasions 4: 619-626.

Koščo J, Košuthová L, Košuth P, Pekárik L. 2010. Non-native fish species in Slovak waters: origins and present status. Biologia, 65: 1057-1063.

Kottelat M, Freyhof J. 2007. Handbook of European freshwater fishes. Kottelat Cornol and Freyhof, Berlin, Germany, 646 p.

Kotovska G, Khrystenko D, Patoka J, Kouba A. 2016. East European crayfish stocks at risk: arrival of non-indigenous crayfish species. Knowl Manag Aquat Ecosyst 417: 37.

Koutsikos N, Economou AN, Vardakas L, Kommatas D, Zogaris S. 2017. First confirmed record of an established population of sailfin molly, Poecilia latipinna (Actinopterygii: Cyprinodontiformes: Poeciliidae) in Europe. Acta Ichthyol Piscat 47: 311-315.

Koutsikos N, Zogaris S, Vardakas L, Tachos V, Kalogianni E, Sanda R, Chatzinikolaou Y, Giakoumi S, Economidis PS, Economou AN. 2012. Recent contributions to the distribution of the freshwater ichthyofauna in Greece. Mediterr Mar Sci 13: 268-277.

Krishnakumar K, Raghavan R, Prasad G, Bijukumar A, Sekharan M, Pereira B, Ali A. 2009. When pets become pests - exotic aquarium fishes and biological invasions in Kerala, India. Curr Sci 97: 474- 476.

Kryss CL, MacKenzie RA, Bruland GL, Shimizu LM. 2008. Impacts of invasive fish on nitrogen dynamics in Hawaiian coastal wetlands. Hawaii Conservation Conference, Honolulu, HI, 29-31.

Lampert KP, Steinlein C, Schmid M, Schartl M. 2007. A haploiddiploid-triploid mosaic of the Amazon molly, Poecilia formosa. Cytogenet Genome Res 119: 131-134.

Lehner PN. 1987. Design and Execution of Animal Behavior Research: An Overview. J Anim Sci 65: 1213-1219.

Lee R. 1970. Latitude and photoperiodism. Arch Met Geoph Biokl 2: 325-332

Lintermans M. 2004. Human-assisted dispersal of alien freshwater fish in Australia. New Zeal J Mar Freshwat Res 38 (3): 481-501.

Lockwood JL, Cassey P, Blackburn T. 2005. The propagule pressure in explaining species invasions. Trends Ecol Evol 20: 223-228.

Maceda-Veiga A, Escribano-Alacid J, de Sostoa A, García-Berthou E. 2013. The aquarium trade as a potential source of fish introductions in southwestern Europe. Biol Invasions 15: 2707-2716.

Marchetti MP, Moyle PB, Levine R. 2004. Alien fishes in California watersheds: Characteristics of successful and failed invaders. Ecol Appl 14: 587-596.

Martin BA, Saiki MK. 2009. Trophic relationships of small nonnative fishes in a natural creek and several agricultural drains flowing into the Salton Sea, and their potential effects on the endangered desert pupfish. Southwest Nat 54: 156-165.

Martin SB, Hitch AT, Purcell KM, Klerks PL, Leberg PL. 2009. Life history variation along a salinity gradient in coastal marshes. Aquatic Biol 8: 15-28.

Matthews WJ. 1998. Patterns in freshwater fish ecology. London, UK: Chapman and Hall, 756.

McDowall RM. 1999. Further feral poeciliid fish in New Zealand fresh waters, with a key to species. New Zeal J Mar Freshwat Res 33: $673-682$. 
McDowall RM. 2006. Fish, fish habitats and fisheries in New Zealand. Aquat Ecosyst Health Manag 9: 391-405.

Meffe GK, Snelson FFJ. An ecological overview of poeciliid fishes. In : Meffe GK, Snelson FFJ, eds, Ecology and evolution of livebearing fishes (Poeciliidae). Prentice Hall, 1989, pp. $13-31$.

Moyle PB, Marchetti MP. 2006. Predicting invasion success: freshwater fishes in California as a model. AIBS Bull 56: 515-524.

NACA. 2005. The Way Forward: Building capacity to combat impacts of aquatic invasive alien species and associated transboundary pathogens in ASEAN countries. Final report of the regional workshop, hosted by the Department of Fisheries, Government of Malaysia, on $12^{\text {th }}-16^{\text {th }}$ July 2004. Network of Aquaculture Centres in Asia-Pacific, Bangkok, Thailand.

Nelson JS, Paetz MJ. 1992. The fishes of Alberta. Edmonton, Canada: University of Alberta Press and the University of Calgary Press, 437 p.

Nico L, Schofield PJ, Neilson M. 2014. Poecilia latipinna. USGS Nonindigenous Aquatic Species Database, Gainesville, FL. http:// nas.er.usgs.gov/queries/FactSheet.aspx?speciesID $=858$ Revision Date: $9 / 29 / 2011$.

Nordlie FG. 2006. Physicochemical environments and tolerances of cyprinodontoid fishes found in estuaries and salt marshes of eastern North America. Rev Fish Biol Fish 16: 51-106.

Nordlie FG, Haney DC, Walsh SJ. 1992. Comparisons of salinity tolerances and osmotic regulatory capabilities in populations of sailfin molly (Poecilia latipinna) from brackish and fresh waters. Copeia 1992: 741-746.

Nowak M, Szczerbik P, Tatoj K, Popek W. 2008. Non;native freshwater fishes in Poland: an overview. AACL Bioflux 1: 173-191.

Papavlasopoulou I, Vardakas L, Perdikaris C, Kommatas D, Paschos I. 2013 Ornamental fish in pet stores in Greece: a threat to biodiversity? Mediterr Mar Sci 15: 126-134

Patoka J, Kopecký O, Vrabec V, Kalous L. 2017. Aquarium molluscs as a case study in risk assessment of incidental freshwater fauna. Biol Invasions 19: 2039-2046.

Peel MC, Finlayson BL, McMahon TA. 2007. Updated world map of the Köppen-Geiger climate classification. Hydrol Earth Syst Sci 11: 1633-1644.

Perdikaris C, Koutsikos N, Vardakas L, Kommatas D, Simonović P, Paschos I, Detsis V, Vilizzi L, Copp GH. 2016. Risk screening of non-native, translocated and traded aquarium freshwater fishes in Greece using Fish Invasiveness Screening Kit. Fish Manag Ecol 23: $32-43$.

Petrescu-Mag IV, Lozinsky LR, Csep L, Petrescu-Mag RM. 2008. Vegetation and predators mediate color pattern frequencies in Poecilia sphenops Valenciennes. AACL Bioflux 1: 51-61.

Piazzini S, Cianfanelli S, Favilli L, Lori E, Manganelli G, Vanni S. 2010. A tropical fish community in thermal waters of Southern Tuscany. Biol Invasions 12: 2959-2965.

Piria M, Simonovic P, Kalogianni E, Vardakas L, Koutsikos N, Zanella D, Ristovska M, Apostolou A, Adrovic A, Mrdak D, Tarkan AS, Milosevic D, Zanella LN, Bakiu R, Ekmekci FG, PovZ M, Korro K, Nikolic V, Skrijelj R, Kostov V, Gregori A, Joy MK.
2018. Alien freshwater fish species in the Balkans-Vectors and pathways of introduction. Fish Fish 19: 138-169.

Ribeiro F, Elvira B, Collares-Pereira MJ, Moyle PB. 2008. Lifehistory traits of non-native fishes in Iberian watersheds across several invasion stages: a first approach. Biol Invasions 10: 89-102.

Riesch R, Tobler M, Plath M. 2015. Hydrogen sulfide-toxic habitats In Riesch R, Tobler M, Plath M, eds.Extremophile fishes: ecology, evolution, and physiology of teleosts in extreme environments, Heidelberg (Germany): Springer, 137-159.

Rixon CAM, Duggan AC, Bergeron NMN, Ricciardi A, MacIsaac HJ. 2005. Invasion risks posed by the aquarium trade and live fish markets on the Laurentian Great Lakes. Biodivers Conserv 14: 1365-1381.

Rodionova MI, Nikitin SV, Borodin PM. 1996. Synaptonemal complex ana lysis of interspecific hybrids of Poecilia (Teleostei, Poecili-dae). Rev Brasil Genet 19: 231-235.

Sakai AK, Allendorf FW, Holt JS, Lodge DM, Molofsky J, With KA, McCauley DE. 2001. The population biology of invasive species. Annu Rev Ecol Evol Syst 32: 305-332.

Scoppettone GG, Rissler PH, Gourley C, Martinez C. 2005. Habitat restoration as a means of controlling non-native species in a Mojave Desert oasis. Restor Ecol 13: 247-256.

Seegers L, De Vos L, Okeyo DO. 2003. Annotated checklist of the freshwater fishes of Kenya (excluding the lacustrine haplochromines from Lake Victoria). J East Afr Nat Hist 92: 11-47.

Semmens BX, Buhle ER, Salomon AK, Pattengill-Semmens CV. 2004. A hotspot of non-native marine fishes: evidence for the aquarium trade as an invasion pathway. Mar Ecol Prog Ser 266: 239-244.

Simpson RG, Allen DM, Sherman SA, Edwards KF. 2015. Fishes of the North Inlet estuary: a guide to their identification and ecology. In : Belle W. University of South Carolina, USA: Baruch Institute Special Publication, $143 \mathrm{p}$.

Snelson FFJ. 1980. A continuation of base-line studies for environmentally monitoring space transportation systems at John F. Kennedy Space Center. KSCTR51-2, Vol. 111, Pt. 2. Ichthyological studies: Sailfin molly reproduction study. NASA Contract Final Rept. 163122, Kennedy Space Center, FL. 173 p.

Timmerman CM, Chapman LJ. 2004. Behavioral and physiological compensation for chronic hypoxia in the live-bearing Sailfin molly (Poecilia latipinna). Physiol Biochem Zool 77: 601-610.

Trexler JC, Travis J, McManus M. 1992. Effects of habitat and body size on mortality rates of Poecilia latipinna. Ecology 73: 22242236.

Vinagre C, Ferreira T, Matos L, Costa MJ, Cabral HN. 2009. Latitudinal gradients in growth and spawning of sea bass, Dicentrarchus labrax, and their relationship with temperature and photoperiod. Estuar Coast Shelf Sci 81: 375-380.

Zieba G, Copp GH, Davies GD, Stebbing P, Wesley K, Britton JR. 2010. Recent releases and dispersal of non-native fishes in England and Wales, with emphasis on sunbleak Leucaspius delineatus. Aquat Invasions. 5: 155-161.

Cite this article as: Koutsikos N, Vardakas L, Kalogianni E, Economou AN. 2018. Global distribution and climatic match of a highly traded ornamental freshwater fish, the sailfin molly Poecilia latipinna (Lesueur, 1821). Knowl. Manag. Aquat. Ecosyst., 419, 23. 